\title{
ESKO AALTONEN (1893-1966) - A LIFETIME OF LOCAL HISTORY
}

\author{
Hannu Lahtonen
}

Last year was one of celebration, not only of Finland's entry into the European Union but also manifestly of Finnish culture. It was one hundred years since the foundation of the country's first local history society at Lohja.

A year before that, on March 9. 1893 a boy who was baptised with the very Finnish name of Esko, was born into the family of a weaving mill worker. Later Esko was to become a major force and pioneer in the local history movement.

The notion of local arts and crafts in Finland was by no means an invention of the 19th century; its roots reach far back into the soil of the national romantic movement. The reconstruction that followed the Great Nordic War (1700-1721) meant for Finland, now belonging to a Swedish monarch, a search for its own identity. For Henrik Gabriel Porthan, one of the prominent figures of the epoch, love of country was a form of love for the local community. Indeed, the Turku Academy of the 18th century formed a centre for Finnish district research. Between 1730 and 1800 some fifty theses on local subjects were published within its circles. For their part, priests and surveyors promoted domestic research through their parish reviews and illustrations.

From 1809 Finland was ruled by an eastern country rather than a western one, as an autonomous Grand Duchy of Russia, and it was during this period that a powerful nationalist feeling evolved, culminating in independence in 1917.

Along with a powerful movement to collect national poetry, epitomized by the national epic, Kalevala, grew an awareness of our own Finnish past. The Finnish Literary Society (Suomalaisen Kirjallisuuden Seura) was founded as early as 1831, and from 1870 the Finnish Ancient Relics Society (Suomen Muinaismuistoyhdistys) sent entire expeditions around the country. Five years later the Finnish Historical Society (Suomen Historiallinen Seura) began and, among other things, started to publish a series of parish reviews.

At the same time began some of decades of collection of museum artefacts was initiated by university students, which resulted in the foundation of the National Museum in 1916. Thus museum collecting gave rise to a national ethnology. 


\section{YOUTH SEEKS ITS PLACE}

The foundation of a society dedicated to the subject is evidence of nascent systematic local historical research. It was through this that the local history movement gradually spread, via the educated intelligentsia, to the wider public. One of the architects of the new kind of movement was Dr. Robert Boldt, whose achievement was the setting up of the country's first district local history society at Lohja in 1894.

The committee for Finnish Local History Research (Suomen Kotiseutututkimuskeskus) was formed in 1908 to coordinate the efforts of the emerging local societies. A year later it began publishing its journal, Kotiseutulehti, in whose columns in 1911 the barely 18-year-old Esko Aaltononen began his enormous output of articles dealing with local history, with a piece called "Place names etc., in Tammela". In fact he even managed to edit this journal at some time during the 1940 s.

But even as a schoolboy at the turn of the century, Esko Aaltonen participated, without meaning to and unaware of it, in the true breakthrough of the local history movement.

In the mid-19th century, a Swede called Axel Wilhelm Wahren founded Finland's third cotton mill, amid the loose collection of dwellings that made up the parish of Tammela, which not only gave its name to the district but was also the opening move in the industrial development of Forssa. In keeping with general trends in Finland, the turn of the century was also a time of cultural and social progress. The first labour club to be formed in the countryside had a decisive effect on the social awa- kening of the working-class population. The first countryside secondary school was also founded at Forssa in 1899. It was from here that Esko Aaltonen passed his university entrance exams in 1913 and the following autumn he registered at the Czarist Finnish Alexander University, now Helsinki University.

Entries in the young schoolboy's diary reveal how this child of an industrial society developed a yearning for the surrounding countryside, its nature and its peasant culture. Blue-covered exercise books from his secondary school days contain studies of local history, natural history observations, stories of adventures, extracts from plays, poems and so on.

"I have begun to sing songs of the home I love so much..." he wrote in his diary in 1912.

\section{NO MORE ROOM FOR ROMANTICISM}

Altonen's student period coincided with the beginnings of systematic local history study in Finland. Only after the general strike of 1905 was there any widescale appreciation of the fact that the old peasant way of life was vanishing fast in the face of modern culture. The educated classes determinedly set about salvaging the material as well as the more abstract relics of this disappearing folk tradition.

University students were naturally involved in this renaissance of the local history movement. The regional students' associations set up special local history research committees, and Aaltonen's Häme Students' Society (Hämäläisosakunta) for example, was the first in Finland to publish in 1916-17 a body of old poems 
Esko Aaltonen on an interviewing tour at Liesjärvi in Tammela in 1928. The interviewee is the owner of the Sipilä farm.

Aaltonen was an eager photographer - note the camera. Photo: The

Museum of South West Häme.

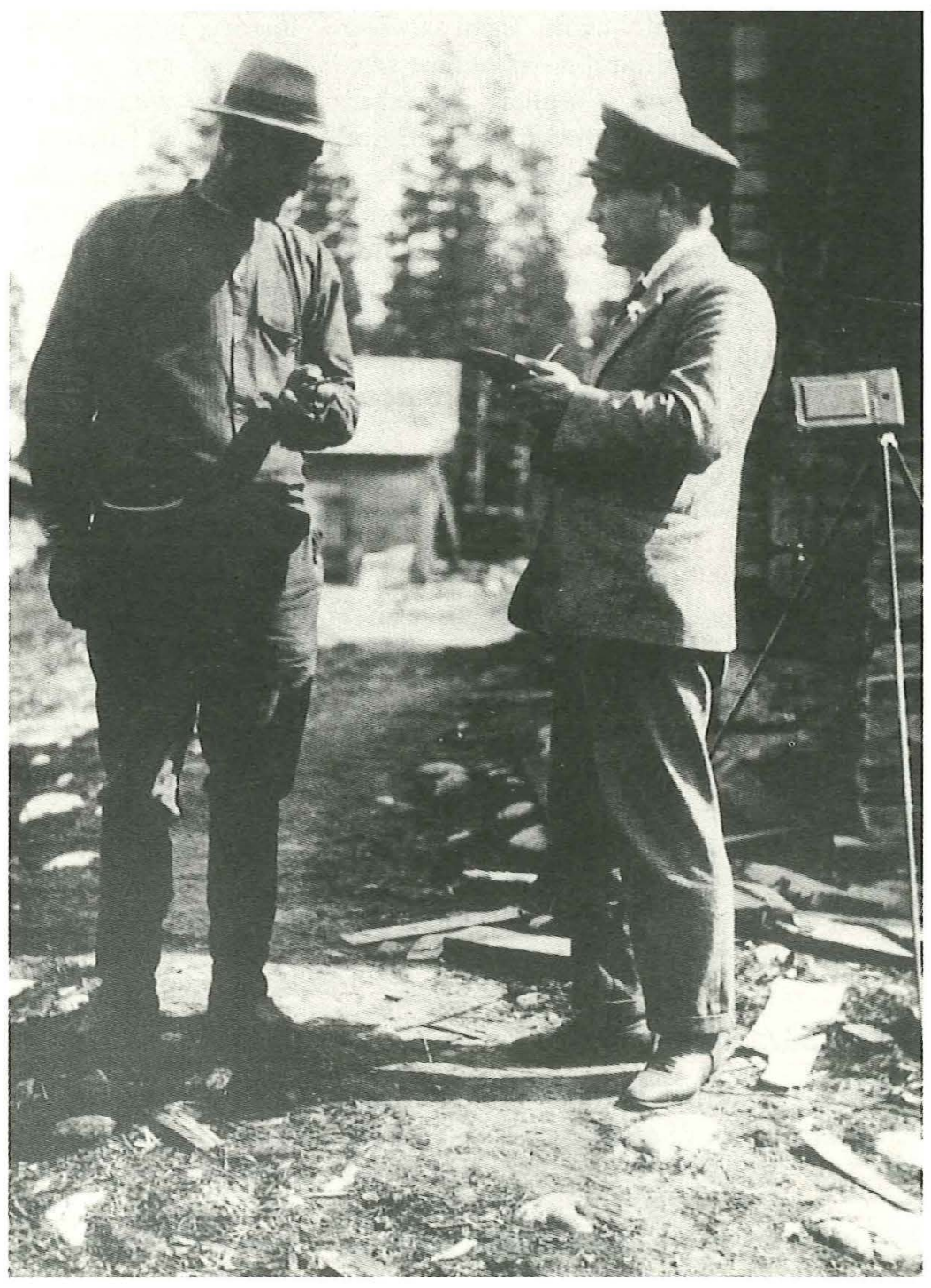

and incantations, following a huge collecting effort.

Aaltonen's contribution to this accumulation of national poetry was enormous in 1914 he collected about a thousand poems and spells from the parishes of southern Häme, about a third of the entire compilation. Aaltonen's share of this accumulation of old Häme verse amounted to a full fifth of the entire Häme poetic tradition collected up to that time.

The push for this local history research 
44 among the students came from a new mood, a social spirit and a nationalist sentiment in society. Gunnar Suolahti, Helsinki University professor and curator of the Häme students' society, became a dominant figure in this movement and also Aaltonen's mentor. Suolahti's ideas contained powerful social overtones and he inspired his students to seek out the roots of the Finnish people. The period of 19 th century romanticism was irretrievably ended.

As a sociology professor at Turku University, Aaltonen reminisced about that period:

In my youth, long ago, I tried to sketch out an overall picture of our peasant culture as it was expressed at the peak of its development, some time in the middle of the last century, before the years of great famine and the upheavals wrought by industrialization. I saw in that relatively motionless, static way of life balance and harmony, beauty and poetry, personality and closeness to nature - I saw all this as the result of centuries of peaceful, balanced development and construction work built on tradition.

\section{THE CALL HOME}

Aaltonen studied Finnish and Scandjnavian history and graduated with an MA. in 1917, after only about three and a half years. But turbulence in Finnish sociery at that time forced him to abandon many of his plans and return to his village in southwest Häme.

Energy survived, however, for the same year he founded his own newspaper, Forssan Lehti, and a little later, as independent Finland began to settle down, a press.

Although Forssan Lehti can be regarded as the first expression of his views on local history, it was the Southwest Häme Local History and Museum Society (LounaisHämeen Kotiseutuja Museoyhdistys) founded in 1923 that on a deliberately practical level became, in all its manifestations, the laboratory for the great idealist.

The aims of the society were defined as the creation of a provincial museum, research into south-west Häme's past and the fostering of local sentiment. Nature research and awareness were also included. The local history of Forssa and the unofficial province of parishes surrounding it was quite obviously Aaltonen's calling. Even in the dummy issue of Forssan Lehti his leader proclaimed the paper's purpose as a unifying force in Southwest Häme. The article further stated in the paper's intention of making the local district known by publishing its history, nature, folk customs and activities.

Aaltonen was the prime mover behind the Local History and Museum Society; it was, for example, on his initiative that Tammela's observation tower was erected on the beautiful Kaukalonharju ridge and the Saari National Park was developed into an enormous meeting place for provincial celebrations into the $1950 \mathrm{~s}$. His initiative was astonishing. He was involved in just about everything that appeared in Forssa at that time. He was secretary and chairman of the Museum Society for a total of 30 years, and managed to participate in various tasks in the municipal life of Forssa village between 1923-33.

Amid all this, his literary output accumulated at a respectable rate: Old Forssa and Its People I and II, A History of Tammela, The origins and Early Years of Forssa, the History of Somerniemi, The History of Somero, An Illustrated Old 
Tammela, and so on. He also started the Local History Society's series of publications, the Southwest Häme Annual Review, which continues to this day.

\section{AT NATIONAL LEVEL}

When the local history movement began to seek new forms of activity during the 1930s, Aaltonen, semi-urbanized for years, became one of its principal figures. The local history work he had done in Southwest Häme for more than a decade was scaled up to a national dimension.

In 1932 he was unexpectedly invited to take part in an extensive book project on the editorial staff of the Finnish Cultural History, (Suomen Kultuurihistoria), whose chairman at that time was Gunnar Suolahti - one of the guiding lights of the local history movement of the beginning of the century and Aaltonen's tutor at Helsinki University. The publisher of this ambitious project was the K.J. Gummerus Oy company at Jyväskylä.

Only two years later, Aaltonen became the literary editor at Gummerus and later managing director until 1939. He simultaneously oversaw an unprecedented blossoming of Gummerus' literary output and the beginning of the national organization of the local history movement. One of the manifestations of the spirit of the time was Kansatieteellinen Filmi Oy the Etnographic Film Company, founded in Helsinki in 1936, with Aaltonen as managing director until it was wound up during the Winter War. His boyhood photographic hobby, which in fact continued with his studies of folk tradition, was replaced by the modern means of communication, the moving film.
Despite its narrow financial base, the company managed every year to arrange a significant number of shoots of folk traditions both at home and among related Finnish populations elsewhere.

\section{FOR THE PEASANT CULTURE}

The historic value of this highly prestigious but idealistic project was that the idea of setting up a peasant culture foundation (Talonspoikaiskultuurisäätio) arose among the activists within its ranks. It was no accident that at the founding conference in 1938, it was Esko Aaltonen who was elected as its chairman. The foundation was in large part his own creation and he only relinquished the chair for health reasons in 1964, two years before his death.

The Peasant Culture Foundation combined scientific folk research with practical ideological activity. For three decades the Finnish Local History Research Central Committee (Suomen Kotiseutututkimuksen Keskusvaliokunta) had pursued the same goals, but faded out in the 1930s. Thus there was no coordinating organization in Finland to give direction to the work on behalf of rural culture. The Peasant Culture Foundation was set up to fill that vacuum.

The primary opus as far as the society's aims were concerned, was Eino Jutikkala's "History of the Finnish Peasant» (Suomen talonpojan historia) published in 1942, followed by Kustaa Vilkuna's and Eino Mäkinen's fine illustrated work "Our Fathers' Jobs" (Isien työ) a year later. Aaltonen's doctoral thesis "Communal mills of south-west Finland" was also published in 1944. Apart from its prolific publication work the foundation also took 
46 on the task in 1939 of publishing the local history magazine, Kotiseutu.

From the beginning the foundation set out to make use of its own research in stressing, through its practical ideological activity, that aspect of the local history movement whose task was to manage and maintain old cultures: nature, village scenery, old buildings, historic relics, traditional customs and so on.

Following the Second World War, Finland was forced to reevaluate its relations with the past, present and future, in all aspects of society. Even Kotiseutu, edited by Aaltonen from 1947 breathed the new spirit of the times. Backward-looking local history expanded to cover nature conservation, maintenance of local districts and rural culture generally. The foundations of modern local history research, cast by Aaltonen, began to harden.

\section{LOCAL HISTORY SOCIETY BECOMES A COORDINATING ORGAN}

Much behind-the-scenes work had to be done to reorganize the disparate local history research. The Peasant Culture Foundation wanted the assistance of a national central organization. The Fund's chairman, Esko Aaltonen, was in practice the chief architect of the reorganization of rural research.

At the conference of local historians in the local history building that Aaltonen himself brought into being in Pirtti in Southwest Häme in 1949, a national umbrella organization was set up. Aaltonen acted as deputy chairman of the society for 10 years from 1951, when he took over as chairman until his death.

During the 1960 s he remembered how «thinking of the broad countryside, there arose in our minds the primary goal of raising the local history ideal to the status of a culturally based national movement.»

At the 1957 cultural history conference Aaltonen was able to divine that "traditional cultural capital and the respect of its memory are beginning to become self-evident to the public.»

Particularly in the 1960s Aaltonen's speeches represented realistic idealism. The enormous changes wrought in society did not pass by the social historian and scientist who had held a sociology professorship at Turku University since 1951.

Cultural education, the essence of which is the transfer of ideal cultural values form one generation to the rising generation, should have enormous support from the local history movement, if only its systematic exploitation is understood. But the counterflow is powerful. Paul Anka and the other pop singers have indeed sung Väinämöinen into the bog.

\section{CULTURE'S KEY WORD IS TRADITION}

The social history viewpoint is apparent in both Esko Aaltonen's research activities and almost all his other writings. He assumed that the key word in all culture is tradition. Traditions make our social heritage, that is, our cultural heritage. It is the idea, not the object itself, that creates the tradition. Traditions are social by nature, and conforming to them gives us a feeling of security, enjoyment and spiritual backbone. Individuals may fulfil themselves only within the confines set by traditions and the means they allow.

The part played by the individual and 
the group in folk culture was a matter of special interest for Aaltonen, who stressed the influence of the social atmosphere of the community on human behaviour.

He examined two aspects of the relationship with the local environment, the individual psychological and the social. Nature, the buildings and other tangible objects do not, in themselves, make up the village. We have a strong feeling for our local community only when we adopt it as a personal experience and are able almost to make it a spiritual thing. The village community thus has a visible and an invisible constituent.

As the result of a long and complex path of progress he concluded that looking back, understanding the work of former generations, was only one of the aims of local history research, though certainly a fundamental one. Just as important is taking care of our present and our future, which we should strive to improve so that the special features of our locality, its uniqueness is not sacrificed to some allembracing move towards standardization.

Translation from Finnish by Joe White

Hannu Lahtonen is a reporter of Kauppalehti

(Finnish Business daily). As a grandson of Esko

Aaltonen he is one of the writers of Aaltonens life his-

tory (published 1993).

Adr: Kauppalehti, PL 189, FIN-00101 Helsinki

Fax +358-0 660383 